\title{
Herpes simplex encephalitis as a complication of neurosurgical procedures: report of 3 cases and review of the literature
}

David A. Jaques ${ }^{*}$, Spyridoula Bagetakou ${ }^{2}$, Arnaud G. L'Huillier ${ }^{3}$, Andrea Bartoli ${ }^{4}$, Maria-Isabel Vargas ${ }^{5}$, Joel Fluss ${ }^{6}$ and Laurent Kaiser ${ }^{3,7^{*}}$

\begin{abstract}
Background: Herpes simplex virus (HSV) is the most common identified cause of focal encephalitis worldwide. However, postoperative HSV encephalitis (HSVE) is a rare complication of neurosurgical procedures and a significant clinical challenge

Method: We describe 3 cases of postoperative HSVE and review all published reports. A total of 23 cases were identified.

Discussion: Clinical heterogeneity represents a diagnostic challenge in the postoperative setting. Cerebral magnetic resonance imaging showed typical findings in a minority of patients only, whereas HSV-specific polymerase chain reaction on the cerebrospinal fluid proved to be a valuable test. The postoperative viral pathophysiology remains a subject of debate. The rate of adverse outcome is high and early antiviral treatment seems to be a strong predictor of clinical outcome.

Conclusion: We recommend early empirical treatment for any patient presenting with post-neurosurgical lymphocytic meningo-encephalitis, and prophylactic antiviral treatment for patients with a history of previous HSVE who will undergo a neurosurgical procedure.
\end{abstract}

Keywords: Herpes simplex virus, Meningitis, Encephalitis, Neurosurgery, Complication, Postoperative

Abbreviations: CNS, Central nervous system; CSF, Cerebrospinal fluid; HSV, Herpes simplex virus; HSVE, Herpes simplex virus encephalitis; IV, Intravenous; PCR, Polymerase chain reaction; POD, Postoperative day.

\section{Key points}

We report 3 cases of postoperative herpes simplex encephalitis and review the existing literature. The importance of early empiric treatment is highlighted. We recommend prophylactic treatment before neurosurgery for patients with a history of previous herpetic encephalitis.

\footnotetext{
* Correspondence: David.Jaques@hcuge.ch; Laurent.Kaiser@hcuge.ch ${ }^{1}$ Division of General Internal Medicine, Geneva University Hospitals, Rue Gabrielle-Perret-Gentil 4, 1205 Geneva, Switzerland

${ }^{3}$ Laboratory of Virology, Division of Infectious Diseases and Division of Laboratory Medicine, Geneva University Hospitals, Rue Gabrielle-Perret-Gentil 4, 1205 Geneva, Switzerland

Full list of author information is available at the end of the article
}

\section{Background}

Herpes simplex virus (HSV) is the most common identified cause of acute and focal sporadic encephalitis in the Western world with an incidence of $1-3$ cases per million inhabitants each year [1]. Without treatment, mortality can be as high as $70 \%$ as opposed to $30 \%$ with adequate treatment and neurological sequelae are frequent, even in treated cases [1]. It has traditionally been recognized that HSV-1 is associated with encephalitis, whereas HSV-2 is a predominant cause of aseptic meningitis. However, a significant overlap exists and more than $15 \%$ of patients with HSV-2 central nervous system (CNS) infection present with encephalitis rather than meningitis [2]. HSV infection is characterized by peripheral nervous system latency and 
potential reactivation from quiescent episome triggered by various stimuli [3]. It is estimated that approximately twothirds of HSV encephalitis (HSVE) cases occur because of reactivation, rather than primary infection [4]. HSVE triggered by neurosurgical procedures per se is a rare occurrence and deserves special attention. Initial management is challenging because early therapy is critical in a setting where serious intracranial infections are caused almost exclusively by iatrogenic bacterial species. In this article, we present 3 post-neurosurgical HSVE cases diagnosed and managed at our center, review the literature on this subject, and propose diagnostic and management recommendations.

\section{Case presentations \\ Case 1}

A 24-year-old man underwent right lateral sub-occipital craniotomy for resection of an epidermoid cyst of the right cerebellopontine angle. Evolution was uneventful and he was discharged at postoperative day (POD) 4 under dexamethasone (4 mg two times per day) for one week. On POD 8, he experienced fever associated with worsening headache. He sought medical attention and was treated with intravenous (IV) ceftriaxone, flucloxacillin and metronidazole (POD 9). The following day, he developed agitated behavior and a decreased level of consciousness. Magnetic resonance imaging (MRI) showed leptomeningeal enhancement in the supra and infratentorial regions without evidence of abscess or empyema (Fig. 1). A lumbar puncture

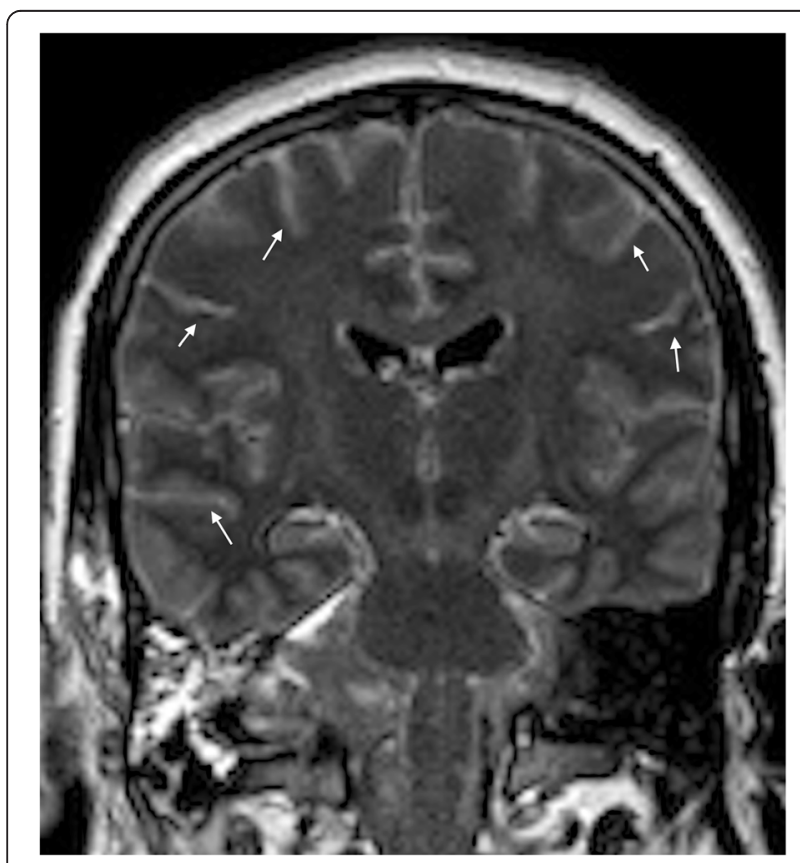

Fig. 1 Coronal FLAIR MRI sequence illustrates a diffuse leptomeningeal enhancement (arrows) after surgery of an epidermoid cyst of the right cerebellopontine angle showed lymphocytic meningitis: 1517 M/l leucocytes, $95 \%$ lympho-monocytes, $1 \mathrm{M} / \mathrm{l}$ erythrocytes, $0.94 \mathrm{~g} / \mathrm{l}$ protein, $2.7 \mathrm{mmol} / \mathrm{l}$ glucose and $3.2 \mathrm{mmol} / \mathrm{l}$ lactate. $\mathrm{He}$ was intubated during $24 \mathrm{~h}$ and treatment was modified to IV meropenem, vancomycin and acyclovir $10 \mathrm{mg} / \mathrm{kg}$ three times daily (POD 11). Cerebrospinal fluid (CSF) cultures remained negative, while the specific polymerase chain reaction (PCR) was positive for HSV-1. Antibiotics were stopped on POD 15 and the patient improved progressively under acyclovir. Subarachnoid hemorrhage with hydrocephaly developed on POD 24. An arteriography showed a ruptured, right anterior inferior cerebellar artery pseudo-aneurysm of traumatic origin attributed to the surgery. Acyclovir treatment was stopped after 21 days. After a 2-month stay, he was discharged with improving right peripheral facial palsy secondary to the hemorrhagic complication and presented no clinical sequelae of the HSV-1 infection.

\section{Case 2}

A 53-year-old man underwent an uncomplicated right pterional craniotomy with total resection of a World Health Organization grade I craniopharyngioma. He was discharged on POD 9 under dexamethasone (3 mg three times daily) with subsequent dose tapering. On POD 18, the patient experienced fever and was drowsier than usual. A computed tomography scan showed a right frontal subdural collection; an empyema could not be excluded (Fig. 2a). However, an MRI showed no sign of empyema but instead leptomeningeal enhancement and lesions compatible with acute ischemic changes in the right corona radiata and centrum semiovale (Fig. $2 b$ ). CSF analysis showed lymphocytic meningitis with $188 \mathrm{M} / \mathrm{l}$ leucocytes, $92 \%$ lympho-monocytes, $26 \mathrm{M} / \mathrm{l}$ erythrocytes, $1.25 \mathrm{~g} / \mathrm{l}$ protein, $1.6 \mathrm{mmol} / \mathrm{l}$ glucose, and $4.2 \mathrm{mmol} / \mathrm{l}$ lactate. No bacteria were detected on direct examination of the fluid. $\mathrm{He}$ was started on IV meropenem, vancomycin, and acyclovir $15 \mathrm{mg} / \mathrm{kg}$ three times daily (POD 19). The next day, revision surgery was performed with cranial flap removal. Operative status was normal and showed no sign of empyema. Surgical samples showed no bacteria on direct examination and cultures remained negative. Broadrange PCR for bacteria on surgical samples was negative and vancomycin and meropenem were stopped on POD 22 and 27, respectively. HSV-2 DNA PCR came back positive on the CSF. IV acyclovir was continued for a total duration of 21 days and he improved rapidly. Neurological status at discharge was comparable to baseline.

\section{Case 3}

A young girl suffered from HSV-1 encephalitis at the age of 11 months. By that time, she had predominant involvement of her right temporal lobe in the form of a multiple area of focal encephalomalacia (Fig. 3a) and exhibited clinically 


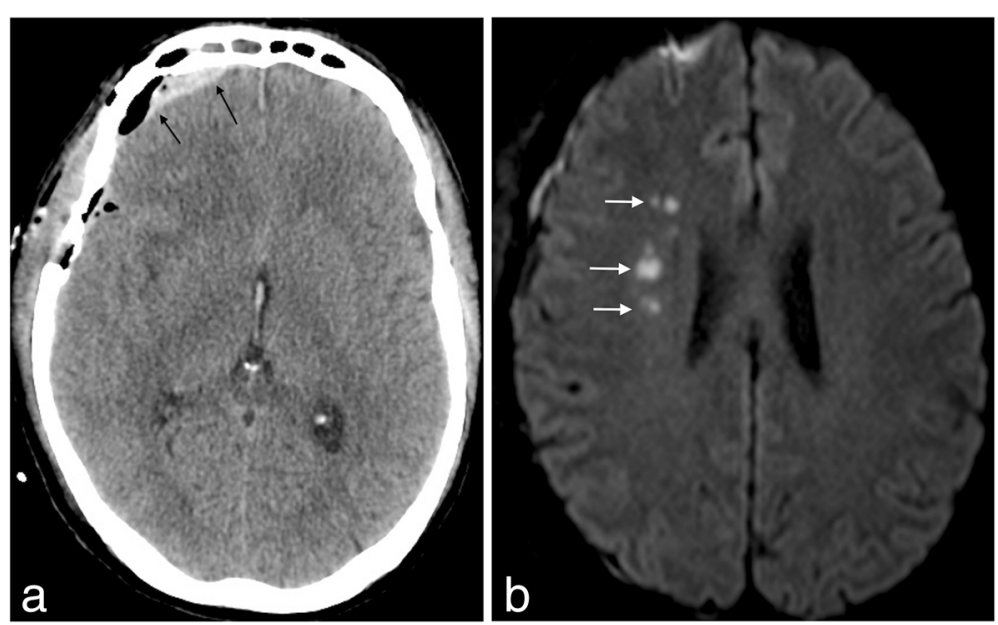

Fig. 2 Post-surgical CT visualization of a right frontal heterogeneous collection (2a, left). MRI showed no empyema but ischemic lesions of the right deep frontal white matter (2b, right)

minimal left-sided weakness. Over the years, her epilepsy had worsened and became progressively intractable. At 12 years of age, epileptic surgery was considered. She underwent a right temporal lobectomy and amygdalohippocampectomy and was discharged at POD 7 without steroids. At POD 11, she presented to the emergency department for headache associated with fever. A worsening level of consciousness at POD 14 prompted a cerebral MRI that demonstrated abnormal signal intensity with vasogenic edema distant from the resected area and compatible with an inflammatory process (Fig. 3b). CSF analysis revealed mild pleocytosis with $91 \mathrm{M} / \mathrm{l}$ leucocytes,
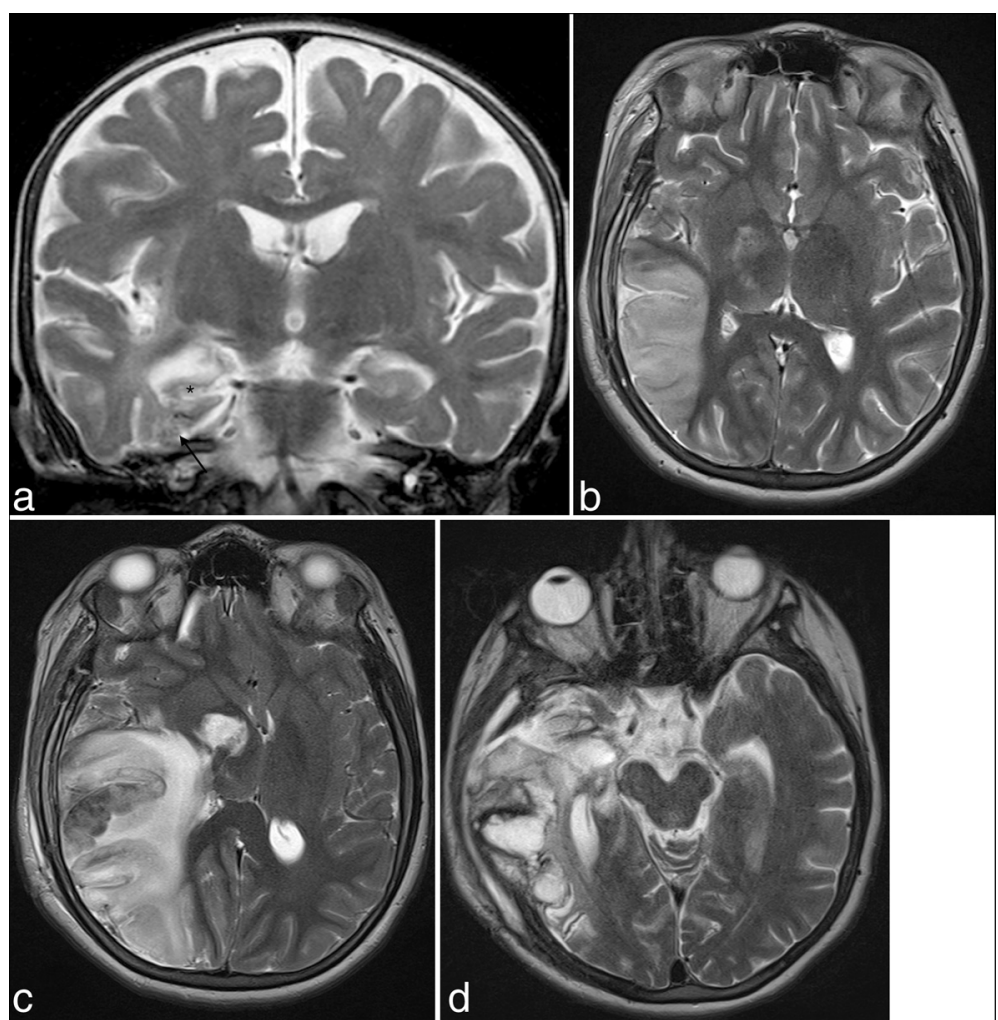

Fig. 3 Sequels of HSVE at the level of the temporal lobe and right hippocampus (3a, upper left, arrows and asterisk). Post-surgical MRI shows areas of suspected encephalitis with high signal on T2 in the right frontal, parietal and temporal lobes at 3 weeks (3b, upper right), associated with hemorrhagic transformation and mass effect one month later (3c, lower left). Follow-up MRI at 45 days showed large sequelae of the temporal lobe (3d, lower right) 
96 \% lympho-monocytes, $837 \mathrm{M} / \mathrm{l}$ erythrocytes, $2.05 \mathrm{~g} / \mathrm{l}$ protein, $1.9 \mathrm{mmol} / \mathrm{l}$ glucose and $2.7 \mathrm{mmol} / \mathrm{l}$ lactate. Empiric IV ceftriaxone and vancomycin were first initiated for presumed superficial wound infection and contiguous bacterial cerebritis. Considering possible HSV relapse, acyclovir $20 \mathrm{mg} / \mathrm{kg}$ three times daily was started $24 \mathrm{~h}$ later. Positive HSV-1 PCR on the CSF confirmed the diagnosis. Four days after the initiation of acyclovir (POD 18) and after a transient improvement, she complained of severe headache and became confused. An urgent MRI revealed a malignant edema with a significant mass effect (Fig. 3c) prompting a rapid decompressive right frontoparietotemporal craniectomy (Fig. 3d). Thereafter, evolution was fortunately favorable. Her neurological status returned to baseline except for a worsening of the preexisting left hemiplegia. Acyclovir was stopped after 21 days, without recurrence of encephalitis.

\section{Methods}

\section{Literature review}

We identified cases in PubMed without any exclusion criterion, using the key words "herpes", "herpetic", "meningitis" or "encephalitis" and one of the following terms: "postoperative", "surgery", "neurosurgery" or "craniotomy". All identified articles and the cited references were searched to identify any other cases.

\section{Results}

A total of 23 cases of HSVE were identified (Table 1). There seems to be no age predisposition as postoperative HSVE can manifest in the pediatric population [5-10], and in adults $[6,11-26]$. A minority of patients only had a previous history of HSVE $[5,7,8,10,15,16,25]$. Most adult patients had uncomplicated neurosurgery for various types of brain tumor. Other surgical indications were: Chiari malformation type 1 [13], refractory epilepsy secondary to previous or presumed HSVE $[15,16,25,26]$ and refractory trigeminal neuralgia [21]. Regarding pediatric cases, neurosurgery was performed for refractory epilepsy secondary to a previous HSVE in 4 patients $[5,7,8,10]$, and CNS tumor for $2[6,9]$. Time-to-symptom onset was highly variable and varied from only a few hours [21] to 3 weeks [18] postsurgery. Postoperative steroids were prescribed in all cases (when documented).

\section{Discussion}

\section{Background}

The vast majority of CNS infections complicating neurosurgery are of bacterial origin and postoperative HSVE remains an exceptional situation, yet not one to miss. Reported cases show great clinical heterogeneity regarding age, type of surgery, and symptom delay (Tables $1 \& 2$ ). This non-specific clinical picture can make early diagnosis difficult and delay appropriate treatment. This is all the more important since postoperative HSVE severity seems comparable to sporadic cases with unfavorable outcome in more than half of patients (Table 3).

\section{Clinical aspects}

Several aspects of the above-reported cases are worth considering. First, the latency observed between the surgery and the first symptoms was longer in patient 2 (POD 18) than most of the previous cases described and only 1 other case showed a longer latency $(\mathrm{POD}>21)$ [18]. This illustrates that there is no definite time frame and the physician must consider HSVE as a potential diagnosis, even several weeks after initial surgery. Second, only 3 other cases of postoperative HSV-2 CNS infection have been described [13, 19, 26] (Table 2), 2 of which [19, 26] presented with encephalitis. This emphasizes that benign aseptic meningitis is not the sole manifestation of HSV-2 CNS infection. This is supported by a recent study showing that more than $15 \%$ of HSV-2 sporadic CNS infection can present with encephalitis, rather than meningitis [2]. Of note, similar to the case reports of Vik-Mo et al. [26] and Perry et al. [19], patient 2 had no prior history of labial or genital herpetic infection. However, such a history is found only in a minority of patients and thus should not lower the physician's pre-test probability of HSVE [27].

\section{Imaging}

CNS imaging is an essential step in the diagnostic workup and characteristic findings of medial temporal lobe and insular involvement on neuroimaging studies contribute significantly to the diagnosis of HSVE. MRI is regarded as the modality of choice in this setting showing early findings with a high sensitivity. It should be emphasized however, that atypical or even normal findings may be found in HSVE, especially in the early stage of the disease [28]. In one series of clinically and biologically diagnosed HSVE, temporal lobe involvement was present in $60 \%$ of cases only and up to $25 \%$ of patients had normal studies (CT or MRI) [29]. The situation seems to be similar in the postoperative setting where patients have been reported to have characteristic [20], atypical [22], or even normal [7, 14] presentations. Cerebral MRI can be difficult to interpret after neurosurgery. Postoperative changes and blood derivatives can mimic infections in diffusion sequences and enhancement can be observed due to breakdown of the hematoencephalic barrier. MRI proved to be of significant help in the diagnostic procedure of our patient 3 where it showed findings compatible with HSVE. Brain imaging showed only aspecific findings in the other two patients, similar to most cases reported previously. Thus, normal postoperative brain imaging should not prevent the clinician from considering HSVE in situations where there is a reasonable clinical suspicion. 
Table 1 Reported Cases of HSVE after Neurosurgery

\begin{tabular}{|c|c|c|c|c|c|c|c|c|c|}
\hline Author, Year & Age & $\begin{array}{l}\text { Previous } \\
\text { HSVE History }\end{array}$ & Diagnosis & Procedure & $\begin{array}{l}\text { Time to } \\
\text { Symptoms }\end{array}$ & Etiology & Steroids & $\begin{array}{l}\text { Treatment } \\
\text { (Time to treatment) }\end{array}$ & Outcome \\
\hline $\begin{array}{l}\text { Fearnside } \\
{[6], 1972}\end{array}$ & 41 & No & Pituitary adenoma & Craniotomy & POD 4 & HSV & Yes & $\begin{array}{l}\text { Idoxuridine IV } \\
\text { (POD 8) }\end{array}$ & Death \\
\hline $\begin{array}{l}\text { Fearnside } \\
{[6], 1972}\end{array}$ & 11 & No & Pituitary adenoma & Craniotomy & POD 8 & HSV & Yes & None & Death \\
\hline $\begin{array}{l}\text { Perry [19], } \\
1998\end{array}$ & 64 & No & $\begin{array}{l}\text { Cranio- } \\
\text { pharyngioma }\end{array}$ & Craniotomy & POD 2 & HSV-2 & Yes & $\begin{array}{l}\text { Acyclovir IV } \\
(\mathrm{POD}>14)\end{array}$ & $\begin{array}{l}\text { Cognitive and } \\
\text { visual sequelae }\end{array}$ \\
\hline $\begin{array}{l}\text { Spuler [24], } \\
1999\end{array}$ & 78 & No & $\begin{array}{l}\text { Parasagittal } \\
\text { meningioma }\end{array}$ & Craniotomy & POD 10 & HSV-1 & Yes & None & Death \\
\hline $\begin{array}{l}\text { Bourgeois } \\
\text { [5], } 1999\end{array}$ & 8 & Yes & Refractory epilepsy & Craniotomy & POD 6 & HSV-1 & NA & $\begin{array}{l}\text { Acyclovir IV } \\
\text { (timing not shown) }\end{array}$ & Complete recovery \\
\hline $\begin{array}{l}\text { Molloy [18], } \\
2000\end{array}$ & 22 & No & Medullo-bastoma & Craniotomy & $\mathrm{POD}>21$ & HSV & Yes & None & Death \\
\hline $\begin{array}{l}\text { Lellouch } \\
\text { [10], } 2000\end{array}$ & 8 & Yes & Refractory epilepsy & Craniotomy & POD 6 & HSV-1 & NA & $\begin{array}{l}\text { Aciclovir } \\
\text { (timing not shown) }\end{array}$ & $\begin{array}{l}\text { Speech } \\
\text { impairment }\end{array}$ \\
\hline $\begin{array}{l}\text { Sheleg [23], } \\
2001\end{array}$ & 28 & No & $\begin{array}{l}\text { Gliobalstoma } \\
\text { multiforme }\end{array}$ & Craniotomy & POD 2 & HSV-1 & Yes & None & Death \\
\hline $\begin{array}{l}\text { Aldea [11], } \\
2003\end{array}$ & 28 & Possible & $\begin{array}{l}\text { Anaplasic oligo- } \\
\text { dendroglioma }\end{array}$ & Craniotomy & POD 7 & HSV-1 & Yes & $\begin{array}{l}\text { Acyclovir IV } \\
\text { (POD 9) }\end{array}$ & Complete recovery \\
\hline $\begin{array}{l}\text { Filipo [12], } \\
2005\end{array}$ & 33 & No & Acoustic neuroma & Mastoidectomy & POD 2 & HSV-1 & Yes & $\begin{array}{l}\text { Acyclovir IV } \\
\text { (POD 11) }\end{array}$ & Complete recovery \\
\hline $\begin{array}{l}\text { Ploner [20], } \\
2005\end{array}$ & 47 & No & Meningioma & Craniotomy & POD 10 & HSV & Yes & $\begin{array}{l}\text { Acyclovir IV } \\
\text { (POD 13) }\end{array}$ & Apathic state \\
\hline $\begin{array}{l}\text { Kwon [9], } \\
2008\end{array}$ & 13 & No & $\begin{array}{l}\text { Cranio- } \\
\text { pharyngioma }\end{array}$ & Craniotomy & POD 15 & HSV & Yes & $\begin{array}{l}\text { Acyclovir IV } \\
\text { (POD 22) }\end{array}$ & $\begin{array}{l}\text { Speech and motor } \\
\text { impairment }\end{array}$ \\
\hline $\begin{array}{l}\text { Jalloh [14], } \\
2009\end{array}$ & 44 & No & Acoustic neuroma & Mastoidectomy & POD 1 & HSV-1 & NA & $\begin{array}{l}\text { Acyclovir IV } \\
\text { (POD 11) }\end{array}$ & Complete recovery \\
\hline $\begin{array}{l}\text { Ihekwaba } \\
{[13], 2009}\end{array}$ & 35 & No & $\begin{array}{l}\text { Type } 1 \text { Chiari } \\
\text { malformation }\end{array}$ & $\begin{array}{l}\text { Sub-occipital } \\
\text { craniectomy }\end{array}$ & POD 14 & HSV-2 & Yes & $\begin{array}{l}\text { Acyclovir IV } \\
(P O D>21)\end{array}$ & Complete recovery \\
\hline $\begin{array}{l}\text { Gong [7], } \\
2010\end{array}$ & 2 & Yes & Refractory epilepsy & Craniotomy & POD 5 & HSV-1 & Yes & $\begin{array}{l}\text { Acyclovir IV } \\
\text { (POD 5) }\end{array}$ & Complete recovery \\
\hline $\begin{array}{l}\text { Lund [16], } \\
2011\end{array}$ & 19 & Yes & $\begin{array}{l}\text { Frontal lobe } \\
\text { epilepsy }\end{array}$ & Craniotomy & POD 10 & HSV & NA & $\begin{array}{l}\text { Acyclovir } \\
\text { (POD 20) }\end{array}$ & Death \\
\hline $\begin{array}{l}\text { Raper [22], } \\
2011\end{array}$ & 65 & No & Ependymoma & Laminectomy & POD 5 & HSV-1 & Yes & $\begin{array}{l}\text { Acyclovir IV } \\
\text { (POD 8) }\end{array}$ & Complete recovery \\
\hline $\begin{array}{l}\text { Mallory [17], } \\
2012\end{array}$ & 49 & No & Acoustic neuroma & Craniotomy & POD 10 & HSV-1 & Yes & $\begin{array}{l}\text { Valacyclovir PO } \\
\text { (POD 10) }\end{array}$ & Complete recovery \\
\hline $\begin{array}{l}\text { Uda [25], } \\
2013\end{array}$ & 20 & Yes & $\begin{array}{l}\text { Medial temporal } \\
\text { lobe epilepsy }\end{array}$ & Craniotomy & POD 11 & HSV & NA & $\begin{array}{l}\text { Acyclovir IV } \\
\text { (POD 11) }\end{array}$ & Complete recovery \\
\hline Kim [8], 2013 & 11 & Yes & Refractory epilepsy & Craniotomy & POD 5 & HSV-1 & NA & $\begin{array}{l}\text { Acyclovir IV } \\
\text { (POD 10) }\end{array}$ & Complete recovery \\
\hline $\begin{array}{l}\text { Prim [21], } \\
2013\end{array}$ & 78 & No & $\begin{array}{l}\text { Trigeminal } \\
\text { neuralgia }\end{array}$ & Rhizothomy & POD 1 & HSV-1 & NA & $\begin{array}{l}\text { Acyclovir IV } \\
\text { (POD 17) }\end{array}$ & $\begin{array}{l}\text { Neuro-psychiatric } \\
\text { sequelae }\end{array}$ \\
\hline $\begin{array}{l}\text { Vik-Mo [26], } \\
2014\end{array}$ & 25 & Possible & $\begin{array}{l}\text { Medial temporal } \\
\text { lobe epilepsy }\end{array}$ & Craniotomy & POD 3 & HSV-2 & NA & $\begin{array}{l}\text { Acyclovir IV } \\
\text { (POD 18) }\end{array}$ & Speech impairment \\
\hline $\begin{array}{l}\text { Presti [15], } \\
2015\end{array}$ & 17 & Yes & Refractory epilepsy & Craniotomy & POD 6 & $\begin{array}{l}\text { No virus } \\
\text { found }\end{array}$ & Yes & $\begin{array}{l}\text { Acyclovir IV } \\
\text { (POD 11) }\end{array}$ & $\begin{array}{l}\text { Motor and } \\
\text { behavioral sequelae }\end{array}$ \\
\hline $\begin{array}{l}\text { Jaques, case } \\
12015\end{array}$ & 24 & No & Epidermoid cyst & Craniotomy & POD 8 & HSV-1 & Yes & $\begin{array}{l}\text { Acyclovir } \\
\text { (POD 11) }\end{array}$ & Complete recovery \\
\hline $\begin{array}{l}\text { Jaques, case } \\
2,2015\end{array}$ & 53 & No & $\begin{array}{l}\text { Cranio- } \\
\text { pharyngioma }\end{array}$ & Craniotomy & POD 18 & HSV-2 & Yes & $\begin{array}{l}\text { Acyclovir IV } \\
\text { (POD 19) }\end{array}$ & Complete recovery \\
\hline $\begin{array}{l}\text { Jaques, case } \\
3,2015\end{array}$ & 12 & Yes & Refractory epilepsy & Craniotomy & POD 11 & HSV-1 & No & $\begin{array}{l}\text { Acyclovir IV } \\
\text { (POD 14) }\end{array}$ & $\begin{array}{l}\text { Mild left } \\
\text { hemiparesy }\end{array}$ \\
\hline
\end{tabular}


Table 2 Clinical Characteristics of HSVE after Neurosurgery

\begin{tabular}{ll}
\hline Age (mean; range) & $32.1 ; 2-78$ \\
Previous HSVE history & $8 / 26(30.1 \%)$ \\
Time-to-symptoms in days (mean; range) & $7.7 ; 1-21$ \\
HSV-2 etiology & $4 / 26(15.4 \%)$ \\
Time to treatment in days (mean; range) & $5.8 ; 0-16$ \\
Death or sequelae & $14 / 26(53.8 \%)$ \\
\hline
\end{tabular}

\section{Cerebrospinal fluid}

CSF analysis in sporadic HSVE typically shows a lymphocytic pleocytosis with normal glucose and a normal or mildly-raised protein level, but normal findings can be observed early in the course of the disease [30]. A small number of erythrocytes are also frequently found in the CSF, potentially reflecting the hemorrhagic nature of the disease [31]. Compared to sporadic cases, CSF findings in the postoperative setting seem not to differ significantly. Lymphocytic pleocytosis was the dominant pattern observed in previous reported cases, but normal findings have also been described [20]. Our first two cases had only marginal amount erythrocytes in the CSF, whereas our patient 3 showed a much higher erythrocyte count, potentially prefiguring the dramatic forthcoming hemorrhaging transformation. CSF interpretation in the postoperative setting can be further complicated by the fact that surgery itself can induce aseptic inflammatory meningitis. Whereas brain biopsy was previously regarded as the gold standard to make a definite diagnosis of HSVE, HSV-1/2 PCR on the CSF is the most efficient test with a sensitivity and specificity of $>95 \%$ and $>99 \%$, respectively [32]. Most previously reported cases were diagnosed by CSF PCR and no further diagnostic procedure was needed when this examination was performed. CSF analysis showing a typical lymphocytic meningitis pattern in all of our 3 cases argued strongly against a classical bacterial infection. Similar to other reported cases, HSV PCR positivity on the CSF led us to the diagnosis of HSVE. We consider this method reliable as we used a fully certified in-house non-commercial PCR assay. In patient 1 , follow-up CSF analyses were ordered in the setting of a neurosurgical complication. After 14 days of IV

Table 3 Clinical Outcome of HSVE after Neurosurgery

\begin{tabular}{lll}
\hline & & Death or sequelae \\
\hline Overall & Children & $14 / 26(53.8 \%)$ \\
& Adults & $4 / 7(57.1 \%)$ \\
& & $10 / 19(52.6 \%)$ \\
No treatment & \\
Treatment & & $5 / 5(100.0 \%)$ \\
& & $9 / 21(42.9 \%)$ \\
& Initiatied $\leq 2$ days $^{b}$ & $0 / 5(0.0 \%)$ \\
& Initiated $\geq 3$ days $^{\mathrm{b}}$ & $8 / 14(57.1 \%)$ \\
\hline
\end{tabular}

aidoxuridine considered as "no treatment"

${ }^{b} 2$ reports excluded as timing of treatment is not indicated $[5,10]$ acyclovir treatment, HSV-1 PCR turned negative. However, it was found to be weakly positive on 2 later occasions (22 and 30 days after treatment onset, respectively). These findings were not correlated with HSVE clinical deterioration and prompted no specific management. Persistence of PCR positivity despite appropriate antiviral treatment has been described and while most patients show CSF PCR negativity after 1 or 2 weeks of treatment, some can retain PCR positivity for as long as 35 days [33]. In this setting, PCR positivity could represent remnant viral DNA. This finding has not been consistently correlated with poor outcome [34].

\section{Physiopathology}

The postoperative viral pathophysiology of HSVE remains a subject of debate. HSVE can be caused by a primary infection by the time of surgery or, more commonly, by a relapse of previous herpetic infection. A clinical relapse seems to harbor two distinct entities [35]: The first is thought to be a post-infectious immune-inflammatory disorder without associated viral replication, while the second involves resumption of active viral replication. This reactivation phenomenon can itself be explained by two distinct mechanisms [1]: a) reactivation of the virus in the trigeminal ganglion with subsequent retrograde axonal transport into the CNS; and b) in situ reactivation in the CNS tissue itself where the virus can be found in a latent form. This last hypothesis could also account for cases without clinically overt past HSVE as viral DNA can be detected in the brain of adults without any neurological disease [36]. In most previous postoperative cases however, the exact pathological mechanism is unknown.

Relapse phenomenon is documented in four adults $([15,16,25]$, patient 3$)$ and four pediatric $([5,7,8,10])$ cases (Table 2). Among these, only one showed HSV positivity on brain tissue (autopsy) [16]. In the seven other cases $([5,7,8,10,15,25]$, patient 3$)$, direct evidence of cerebral viral presence could not be found or was unavailable. As no evidence of in situ latency could be found, reactivation from an extra-cerebral site probably accounts for some of these cases. Peripheral reactivation is also the likely mechanism in one report based on HSV serological status before and after the clinical event [11]. The same mechanism is likely in our patient 2 where HSV-2 DNA PCR was positive on the CSF and standard serological studies showed a pattern consistent with past infection. Serum HSV DNA PCR, intrathecal HSV-2 specific IgG synthesis (Tibbling-Link index), and HSV-1/2 immunostaining, as well as PCR on brain biopsy, were all negative. Globally, these results favor reactivation of the virus in a sensory ganglion with subsequent retrograde axonal transport into the brain as no evidence of primary infection or in situ latency could be found. In our patient 3, who presented with HSVE relapse, HSV DNA PCR was 
negative on the operative specimen, but positive in CSF at the time of diagnosis suggesting that peripheral reactivation started after the surgery. However, the coexistence of an immune-inflammatory process is likely and might explain the unusual diffuse inflammatory change on MRI and the subsequent malignant edema that developed under antiviral therapy. Finally, a pure immune-inflammatory phenomenon without any viral replication is likely in Lo Presti's patient as HSV DNA was not found in CSF or brain tissue [15]. This is supported by the atypical extensive gray and white matter findings on MRI. An inability to detect viral presence in brain tissue or CSF is not uncommon in HSVE sporadic relapse and led several to speculate an immune-mediated mechanism [37] whereas autoantibodies directed against NMDA receptors have been detected in some patients during the course of an initial episode of HSVE [38]. Armangue et al. recently studied eight teenagers and adults with HSVE relapse and showed that 5 had CSF antibodies against NMDA receptors and three against unknown neuronal cell surface proteins whereas CSF PCR for HSV was negative in all patients. Accurate characterization of the underlying pathophysiological mechanism could prove important as prompt immunotherapy resulted in substantial neurological improvement in these patients [39].

Classical stimuli triggering HSV reactivation include fever, local trauma, physical or emotional stress, exposure to ultraviolet light, hormonal imbalance, and immunosuppression [3]. In agreement with previous reports, we postulate that surgical stress and trauma, as well as corticosteroid use, may facilitate HSV reactivation in the postoperative period. Minimal stimulation to the trigeminal sensory root seems to be sufficient to reactivate latent HSV in humans [40], while dexamethasone has been shown to induce HSV-1 reactivation in vitro in a dosedependent manner [41]. Patients 1 and 2, but not patient 3, received high-dose dexamethasone after surgery. All previous described cases received steroids, except for eight cases where steroid use was not documented $[5,8,10,14,16,21,25,26]$.

Finally, host factors might play an important role in HSVE pathophysiology and it has been hypothesized that late relapses could be related to specific immunological defects resulting in a particular susceptibility to HSV cerebral infection [42]. Mutations in the interferon pathway, and more specifically in UNC93B1 and TLR3 genes, seem to confer selective susceptibility to HSV infections [43]. Our patient 3 has been tested for these specific mutations but results came back negative.

\section{Diagnosis}

A diagnosis of encephalitis can be accurately defined using the International Encephalitis Consortium case definition [44]. Based on these criteria, our patient 3 meets criteria for confirmed encephalitis with altered level of consciousness, fever, abnormal CSF and imaging as well as documented HSV-1 in CSF. Patients 1 and 2 on the other hand would only qualify for possible encephalitis as imaging showed no specific sign of encephalitis. We still think that encephalitis is more likely than meningitis based on suggestive clinical findings: Patient 1 presented predominantly with agitated behavior and decreased level of consciousness requiring intubation. Moreover, despite rapid improvement under antiviral treatment, opposing behavior and psychomotor slowing persisted for a few days. In patient 2 , delirium and temporal disorientation out of proportion with the septic state pointed towards encephalitis rather than meningitis. Of note, electroencephalographic data were unfortunately unavailable for these two patients.

Two elements can explain the atypical imaging in patients 1 and 2. First, the MRI was realized on the same day the encephalitic symptoms began possibly accounting for an early false negative result $[28,29]$. Second, a theoretical possibility exists that these two patients suffered from an immune-inflammatory predominant form of relapse. As stated elsewhere [5], findings favoring this hypothesis are the behavioral dominant clinical picture without focal deficit and the atypical neuroimaging results.

\section{Treatment and outcome}

Early treatment is of prime importance in HSVE and represents a major clinical challenge for two reasons. First, the pathological process in the brain is usually well-advanced when patients come to clinical attention and, second, initial signs and symptoms are usually non-specific [30]. Based on the 26 postoperative reported cases, appropriate antiviral treatment seems to be a strong predictor of clinical outcome since death or neurological sequelae were observed in $100 \%$ of untreated patients as opposed to $43 \%$ in the treatment group (Table 3 ). In addition, complete recovery was universally observed when specific treatment was initiated 2 or fewer days after symptom onset. By contrast, death or neurological sequelae were reported in $57 \%$ of cases when the treatment was administered 3 or more days after symptom onset. This finding is in agreement with the fact that treatment delay was independently associated with poor clinical outcome [45]. In patients 1 and 2, acyclovir treatment was started less than 3 days after symptom onset, thus allowing complete recovery. In patient 3 , antiviral treatment was initiated at day 4 after symptom onset, possibly accounting for the mild neurological sequelae. Our three patients have been treated with 21 days of IV acyclovir: $10 \mathrm{mg} / \mathrm{kg}$ two times daily, $15 \mathrm{mg} / \mathrm{kg}$ two times daily, and $20 \mathrm{mg} / \mathrm{kg}$ two times daily (patients 1,2 and 3, respectively). Given the rarity of postoperative HSVE, no established guidelines exist regarding treatment. For HSV-1 sporadic cases, the Infectious Diseases Society of America 2008 guidelines recommend $10 \mathrm{mg} / \mathrm{kg}$ two times daily for 
$14-21$ days in the adult population $(20 \mathrm{mg} / \mathrm{kg}$ in neonates). Some experts advocate a slightly higher dosage of $15 \mathrm{mg} / \mathrm{kg}$ two times daily. Of note, although presenting with encephalitis, patient 2 suffered from HSV-2 infection. As reported recently [27], there is no standard approach to the treatment of sporadic HSV-2 CNS infection. For HSV-2 meningitis, expert opinion usually recommends IV acyclovir $10 \mathrm{mg} / \mathrm{kg}$ two times daily for 10-14 days with a possible per os switch, but some argue that no treatment is needed for a first and uncomplicated episode. No guidelines exist regarding HSV-2 encephalitis treatment. Since HSV-2 encephalitis can induce neurological sequelae in a significant percentage of cases [2], we recommend to treat these patients as if they had HSV-1 encephalitis.

\section{Conclusions}

Although the vast majority of infectious complications of neurosurgical procedures are of bacterial origin, postoperative HSVE is an established entity. Although HSV1 is usually the causative agent, HSV-2 can also cause an encephalitic pattern. Given the severity of the disease and the prognostic implication of treatment delay, prompt initiation of IV acyclovir is of prime importance. Thus, we recommend empirical acyclovir treatment in the appropriate clinical setting whenever CSF analysis is consistent with viral meningo-encephalitis. CSF viralspecific PCR together with MRI brain imaging are diagnostic modalities of choice. In agreement with other experts $[5,11,15,16]$, we recommend prophylactic antiviral treatment for patients with an HSVE previous history undergoing neurosurgery. Considering that postoperative HSVE is rare, potentially overlooked and always severe, randomized controlled studies are improbable and clinicians should adapt their clinical practice based on these data.

\section{Acknowledgments}

We thank Dr. Shen-Ying Zhang for performing the genetic analysis, Prof. Renaud Du Pasquier for his valuable insight as well as Ms. Rosemary Sudan for her excellent support in the preparation of this manuscript.

\section{Funding}

Not applicable.

\begin{abstract}
Authors' contributions
D.A.J, S.B and A.G.L acquired the data, reviewed the literature, interpreted the data and wrote the manuscript. A.B and M.I.V acquired the data and contributed to the writing of the manuscript. J.F and L.K supervised interpretation of the data, revised the manuscript and gave final approval for publication. All authors read and approved the final manuscript.
\end{abstract}

\section{Competing interest}

The authors declare that they have no competing interests.

\section{Consent to publish}

All presented cases or their legal guardian provided consent to publish according to institutional guidelines.
Ethics, consent and permissions

All presented cases or their legal guardian provided consent to data collection and use according to institutional guidelines.

\section{Author details}

${ }^{1}$ Division of General Internal Medicine, Geneva University Hospitals, Rue Gabrielle-Perret-Gentil 4, 1205 Geneva, Switzerland. ²Division of General Pediatrics, Child and Adolescent Department, Geneva University Hospitals, Geneva, Switzerland. ' 2 Laboratory of Virology, Division of Infectious Diseases and Division of Laboratory Medicine, Geneva University Hospitals, Rue Gabrielle-Perret-Gentil 4, 1205 Geneva, Switzerland. ${ }^{4}$ Neurosurgery Division, Department of Clinical Neurosciences, Geneva University Hospitals, Geneva, Switzerland. ${ }^{5}$ Neuroradiology Department, Geneva University Hospitals, Geneva, Switzerland. ${ }^{6}$ Pediatric Neurology Unit, Pediatric Subspecialties Service, Geneva University Hospitals, Geneva, Switzerland. ${ }^{7}$ University of Geneva Medical School, Geneva, Switzerland.

Received: 17 March 2016 Accepted: 17 May 2016

Published online: 23 May 2016

\section{References}

1. Steiner I, Kennedy PGE, Pachner AR. The neurotropic herpes viruses : herpes simplex and varicella-zoster. Lancet. 2007;6:1015-28.

2. Moon S, Kim T, Lee E. Comparison of clinical manifestations, outcomes and cerebrospinal fluid findings between herpes simplex type 1 and type 2 central nervous system infections in adults. J. Med. ... [Internet]. 2014 [cited 2015 Jan 3];86:1766-71. Available from: http://www.ncbi.nlm.nih.gov/ pubmed/25042344

3. Widener RW, Whitley RJ. Herpes simplex virus. Handb. Clin. Neurol. [Internet]. 2014 [cited 2015 Jul 5];123:251-63. Available from: http://www. ncbi.nlm.nih.gov/pubmed/25015489

4. Perng $\mathrm{G}-\mathrm{C}$, Jones $\mathrm{C}$. Towards an understanding of the herpes simplex virus type 1 latency-reactivation cycle. Interdiscip Perspect Infect Dis. 2010;2010:262415.

5. Bourgeois M, Vinikoff L, Lellouch-Tubiana A, Sainte-Rose C. Reactivation of herpes virus after surgery for epilepsy in a pediatric patient with mesial temporal sclerosis: case report. Neurosurgery. 1999;44:633-5. discussion 635-6. Available from: http://www.ncbi.nlm.nih.gov/pubmed/10069600.

6. Fearnside M, Grant J. Acute necrotizing encephalitis complicating bifrontal craniotomy and pituitary curettage: Report of two cases. J. Neurosurg. [Internet]. 1972 [cited 2015 Jan 3];499-502. Available from: http://thejns.org/ doi/abs/10.3171/jns.1972.36.4.0499

7. Gong T, Bingaman W, Danziger-Isakov L, Tuxhorn I, Goldfarb J. Herpes simplex virus reactivation after subtotal hemispherectomy in a pediatric patient. Pediatr Infect Dis J. 2010;29:1148-50. http://www.ncbi.nlm.nih.gov/ pubmed/20622709.

8. Kim SH, Lee SG, Kim SH, Kim DS, Kim HD. Relapsed herpes simplex virus encephalitis after epilepsy surgery. J epilepsy Res. 2013;3:28-31. http://www. pubmedcentral.nih.gov/articlerender. fcgi?artid=3957312\&tool=pmcentrez\&rendertype=abstract.

9. Kwon J-W, Cho B-K, Kim EC, Wang K-C, Kim S-K. Herpes simplex encephalitis after craniopharyngioma surgery. J Neurosurg Pediatr. 2008;2:355-8. http:// www.ncbi.nlm.nih.gov/pubmed/18976107.

10. Lellouch-Tubiana A, Fohlen M, Robain O, Rozenberg F. Immunocytochemical characterization of long-term persistent immune activation in human brain after herpes simplex encephalitis. Neuropathol Appl Neurobiol. 2000;26:285-94.

11. Aldea S, Joly L-M, Roujeau T, Oswald A-M, Devaux B. Postoperative herpes simplex virus encephalitis after neurosurgery: case report and review of the literature. Clin Infect Dis. 2003;36:e96-9. http://www.ncbi.nlm.nih.gov/ pubmed/12652407.

12. Filipo R, Attanasio G, De Seta E, Viccaro M. Post-operative Herpes simplex virus encephalitis after surgical resection of acoustic neuroma: a case report. J Laryngol Otol. 2005;119:558-60. http://www.ncbi.nlm.nih.gov/pubmed/16175983.

13. Ihekwaba UK, Battersby RD. Type 2 herpes simplex reactivation after craniocervical decompression for hind brain hernia and associated syrinx. $\mathrm{Br}$ J Neurosurg. 2009;23:326-8.

14. Jalloh I, Guilfoyle MR, Lloyd SKW, Macfarlane R, Smith C. Reactivation and centripetal spread of herpes simplex virus complicating acoustic neuroma resection. Surg Neurol. 2009;72:502-4. http://www.ncbi.nlm.nih.gov/ pubmed/19631366. 
15. Lo Presti A, Weil AG, Niazi TN, Bhatia S. Herpes simplex reactivation or postinfectious inflammatory response after epilepsy surgery: Case report and review of the literature. Surg Neurol Int. 2015;6:47. http://www. pubmedcentral.nih.gov/articlerender. fcgi?artid=4392527\&tool=pmcentrez\&rendertype=abstract.

16. Lund M. Herpes simplex virus reactivation and encephalitis after topectomy. J Pediatr Health Care. 2011;25:323-7. http://www.ncbi.nlm.nih.gov/pubmed/ 21867861.

17. Mallory GW, Wilson JW, Castner ML, Driscoll CLW, Link MJ. Herpes simplex meningitis after removal of a vestibular schwannoma: case report and review of the literature. Otol Neurotol. http://www.ncbi.nlm.nih.gov2012;33: 1422-5. http://www.ncbi.nlm.nih.gov/pubmed/22975906.

18. Molloy S, Allcutt D, Brennan P, Farrell MA, Perryman R, Brett FM. Chemotherapy, Surgery, and Stereotactic Radiotherapy for Medulloblastoma. Arch Pathol Lab Med. 2000;124:1809-12.

19. Perry JD, Girkin CA, Miller NR, Kerr DA. Herpes simplex encephalitis and bilateral acute retinal necrosis syndrome after craniotomy. Am J Ophthalmol. 1998;126:456-60. http://linkinghub.elsevier.com/retrieve/pii/ S0002939498001081.

20. Ploner M, Turowski B, Gabriele W. Herpes encephalitis after meningioma resection. Neurology. 2005:65:1674-5.

21. Prim N, Benito N, Montes G, Pomar V, Molet J, Rabella N. Human herpesvirus 1 meningoencephalitis after trigeminal neuralgia surgery. J Infect. 2013;67:79-81.

22. Raper DMS, Wong A, McCormick PC, Lewis LD. Herpes simplex encephalitis following spinal ependymoma resection: case report and literature review. J Neurooncol. 2011;103:771-6. http://www.ncbi.nlm.nih.gov/pubmed/20941525.

23. Sheleg S, Nedzved M, Nedzved A, Kulichkovskaya I. Contamination of glioblastoma multiforme with type 1 herpes simplex virus. J. Neurosurg. 2001;95

24. Spuler A, Blaszyk H, Parisi JE, Davis DH. Herpes simplex encephalitis after brain surgery: case report and review of the literature. J Neurol Neurosurg Psychiatry. 1999;67:239-42. http://jnnp.bmj.com/cgi/doi/10.1136/jnnp.67.2.239.

25. Uda T, Koide R, Ito H, Hosono A, Sunaga S, Morino M. Relapse of herpes simplex virus encephalitis after surgical treatment for temporal lobe epilepsy: Rare complication of epilepsy surgery. J Neurol. 2013;260:318-20.

26. Vik-Mo EO, Krossnes BK, Stanisic M, Egge A, Holter E, Taubøll E, et al. Reactivation of occult herpes simplex meningoencephalitis after temporal lobe resection for refractory epilepsy-a case report. Seizure. 2014;23:321-3.

27. Landry ML, Greenwold J, Vikram HR. Herpes simplex type-2 meningitis: presentation and lack of standardized therapy. Am J Med. 2009;122:688-91. http://www.ncbi.nlm.nih.gov/pubmed/19559173.

28. Höllinger $P$, Matter L, Sturzenegger M. Normal MRI findings in herpes simplex virus encephalitis. J Neurol. 2000;247:799-801.

29. Wasay M, Mekan SF, Khelaeni B, Saeed Z, Hassan A, Cheema Z, et al. Extra temporal involvement in herpes simplex encephalitis. Eur J Neurol. 2005;12: 475-9. http://www.ncbi.n/m.nih.gov/pubmed/15885053.

30. Baringer JR. Herpes simplex infections of the nervous system. Neurol Clin. 2008;26:657-74. http://www.ncbi.nlm.nih.gov/pubmed/18657720.

31. Whitley RJ, Soong SJ, Linneman C, Liu C, Pazin G, Alford CA. Herpes simplex encephalitis. Clinical Assessment. JAMA. 1982;247:317-20. http://www.ncbi. nlm.nih.gov/pubmed/6275134.

32. Tunkel AR, Glaser CA, Bloch KC, Sejvar JJ, Marra CM, Roos KL, et al. The management of encephalitis: clinical practice guidelines by the Infectious Diseases Society of America. Clin Infect Dis. 2008;47:303-27. http://www. ncbi.nlm.nih.gov/pubmed/18582201.

33. Anderson NE, Powell KF, Croxson MC. A polymerase chain reaction assay of cerebrospinal fluid in patients with suspected herpes simplex encephalitis. J Neurol Neurosurg Psychiatry. 1993;56:520-5.

34. Malm G, Forsgren M. Neonatal herpes simplex virus infections: HSV DNA in cerebrospinal fluid and serum. Arch Dis Child Fetal Neonatal Ed. 1999;81:F24-9.

35. De Tiège $X$, Rozenberg F, Des Portes V, Lobut JB, Lebon P, Ponsot G, et al. Herpes simplex encephalitis relapses in children: differentiation of two neurologic entities. Neurology. 2003;61:241-3.

36. Gordon L, McQuaid S, Cosby S. Detection of herpes simplex virus (types 1 and 2) and human herpesvirus 6 DNA in human brain tissue by polymerase chain reaction. Clin Diagn Virol. 1996;6:33-40. http://www.sciencedirect. com/science/article/pii/0928019795002030.

37. Sköldenberg B, Aurelius E, Hjalmarsson A, Sabri F, Forsgren M, Andersson B, et al. Incidence and pathogenesis of clinical relapse after herpes simplex encephalitis in adults. J Neurol. 2006:253:163-70.
38. Prüss H, Finke C, Höltje M. N-methyl-D-aspartate receptor antibodies in herpes simplex encephalitis. Ann Neurol. 2012;72:902-11. http:// onlinelibrary.wiley.com/doi/10.1002/ana.23689/full.

39. Armangue T, Erro ME, Portilla- JC, Muñoz-cabello B, González-gutiérrez- L, González G. Autoimmune post - herpes simplex encephalitis of adults and teenagers. 2015

40. Pazin GJ, Ho M, Jannetta PJ. Reactivation of Herpes Simplex Virus after Decompression of the Trigeminal Nerve Root. J Infect Dis. 1978;138:405-9. http://jid.oxfordjournals.org/content/138/3/405.short.

41. Halford WP, Gebhardt BM, Carr DJ. Mechanisms of herpes simplex virus type 1 reactivation. J Virol. 1996:70:5051-60. http://www.pubmedcentral.nih.gov/ articlerender.fcgi?artid=190459\&tool=pmcentrez\&rendertype=abstract.

42. De Tiège X, Rozenberg F, Burlot K, Gaudelus J, Ponsot G, Héron B. Herpes simplex encephalitis: diagnostic problems and late relapse. Dev Med Child Neurol. 2006:48:60-3.

43. Lafaille FG, Pessach IM, Zhang S-Y, Ciancanelli MJ, Herman M, Abhyankar A, et al. Impaired intrinsic immunity to HSV-1 in human iPSC-derived TLR3deficient CNS cells. Nature. 2012;491:769-73. http://www.pubmedcentral.nih gov/articlerender.fcgi?artid=3527075\&tool=pmcentrez\&rendertype=abstract.

44. Venkatesan A, Tunkel AR, Bloch KC, Lauring AS, Sejvar J, Bitnun A, et al. Case definitions, diagnostic algorithms, and priorities in encephalitis: Consensus statement of the international encephalitis consortium. Clin Infect Dis. 2013;57:1114-28.

45. Raschilas F, Wolff M, Delatour F, Chaffaut C, De Broucker T, Chevret S, et al. Outcome of and prognostic factors for herpes simplex encephalitis in adult patients: results of a multicenter study. Clin Infect Dis. 2002;35:254-60.

\section{Submit your next manuscript to BioMed Central and we will help you at every step:}

- We accept pre-submission inquiries

- Our selector tool helps you to find the most relevant journal

- We provide round the clock customer support

- Convenient online submission

- Thorough peer review

- Inclusion in PubMed and all major indexing services

- Maximum visibility for your research

Submit your manuscript at www.biomedcentral.com/submit
) Biomed Central 